\title{
ANALYSIS OF NEARLY ZERO ENERGY RESIDENTIAL BUILDING IN MUSCAT
}

\author{
Hafiz Zafar Sharif1, 3*, A.M. Leman", ", Aissa Nasser Krizou ${ }^{3, ~ *}$, Mohammad Tala't Ahmed Al-Tarawne ${ }^{4,}$, \\ Muthuraman Subbiah ${ }^{5,}{ }^{*}$, Muna AL-Farsi6, ${ }^{*}$
}

\begin{abstract}
The building sector is the largest consumer of the primary sources of energy worldwide. The most commonly used primary sources of energy to generate electricity are oil, coal, peat, shale, natural gas, nuclear, hydro, renewables, biofuels, and waste. The energy demand by the building sector is about $40 \%$ of the world's energy production.Net Zero Energy Buildings (NZEBs) is the best solution recommended by the energy experts to reduce substantial pressure on primary sources of energy contributed by the building sector. There is a marginal gap between estimates made during the design stage and actual energy performance of residential buildings, primarily due to a lack of understanding of the factors affecting energy use and whole building simulations software limitations. The purpose of this research work was to conduct a comparative analysis of a predicted versus actual energy consumption of prototype Net Zero Energy Building (NZEB) constructed at Higher College of Technology, Muscat. Hourly Analysis Program (HAP V4.2) was used to predict energy demand of NZEB at HCT and same size regular house in Muscat. PVWatts calculator was used to determining possible power generation by the PV system installed on the roof in the form of a canopy. The constructed house was tested for one month to perform multiple tasks as per competition requirements in which one of the major tasks was to produce onsite energy production by PV panel's equivalent to the energy consumed by the house. The actual energy consumption results were compared with the simulated result and observed that actual energy demand of house was approximately $20 \%$ lower than that predicted by the simulation tool. The comparison of simulation results between NZEB and regular house indicated $61.24 \%$ less energy demand of NZEB, mainly due to less HVAC load. The simulation result for BEI of NZEB showed $87.20 \mathrm{kWh} / \mathrm{m}^{2} /$ year as compare to 225.1 $\mathrm{kWh} / \mathrm{m}^{2} /$ year for same size regular house. The simulated result obtained from PVWatts calculator for competition period and actual production of an installed PV system at the top roof showed a minor deviation of $0.73 \%$ only. It is also observed from the results during the competition period house exported $1221 \mathrm{kWh}$ energy to the grid.
\end{abstract}

\section{Keywords: Zero Energy Buildings, Energy Consumption, Eco House, Energy Balancing}

\section{INTRODUCTION}

The building sector is the largest consumer of the primary source of energy worldwide like oil, coal, peat, shale, natural gas, nuclear, hydro, renewables, biofuels, and waste. International Energy Agency (IEA) reported in 2013 that the buildings sector's final energy utilization reached 2794 million tonnes of oil equivalent (Mtoe); twofold between 1971 and 2010 [1]. Primary energy supply will be under substantial pressure by the buildings sector demand projected to grow by an additional 838 Mtoe by 2035 compared to 2010 .

The energy demand by the building sector is $40 \%$ of the world's energy production [2] however, according to Internal Energy Agency statistics for Oman in the year 2015, the residential building sector consumed $47.5 \%$ of the produced energy which is $7.5 \%$ higher than the average demand of building sector worldwide due to hot and arid climate of Muscat. The primary sources of energy for power generation in Oman are gas $(97.36 \%)$ and oil $(2.63 \%)$ respectively [3].

\footnotetext{
${ }^{1}$ Research Scholar, Universiti Tun Hussein Onn Malaysia, Batu Pahat, Johor, Malaysia

${ }^{2}$ Universiti Tun Hussein Onn Malaysia, Batu Pahat, Johor, Malaysia

3,4,5,6 Higher College of Technology, Muscat, Oman

E-mail:zafar.sharif@hct.edu.om, mutalib@uthm.edu.my, muthu9678@gmail.com

ORCID ID: https://orcid.org/0000-0002-2369-0281, https://orcid.org/0000-0001-7365-0483, https://orcid.org/0000-0002-0190-

7582, https://orcid.org/0000-0002-006385904, http://orcid.org/0000-0002-3005-5905, https://orcid.org/0000-0001-7968-0544

Manuscript Received 21 March 2018, Accepted 21 July 2018
} 
To address the rising energy demand in the building sector, industry leaders and researchers have committed to developing net-zero energy buildings (NZEBs). These highly energy-efficient buildings produce, and export renewable energy produced onsite as much energy as they consume from the grid annually [4]. These transformations of buildings as an energy generator are well known as a net-zero energy building, also known as zero-energy building, or net-zero building [5].

Agencies, policymakers, Societies, researchers, universities, HVAC companies, Economic leaders, recognize the vision of Net Zero Energy Buildings (NZEBs). For example,

- ENERPOS is a French national research project on Net Zero Energy Buildings Design in hot/tropical climates. ENERPOS project is (a collaboration between three French university research laboratories and two HVAC companies) focused on the development of new methods and tools for the design of Net Zero Energy Buildings in hot/ tropical climates [6].

- Asia-Pacific Economic Cooperation Forum (APEC) declaration about "Nearly (Net) Zero Energy Building Best Practices and Energy Reduction Comparative Study project" it is decided by using 2005 as a base year to reduce APEC's aggregate energy intensity 45 per cent by 2035. It is also decided to promote the renewable and sustainable use of clean energy within the APEC region [7].

- The Energy Performance of Buildings Directive 2010/31/EU (EPBD recast) at the European level is the main governmental tool, for improving the energy efficiency of buildings. One of the key elements of the EPBD recast Article 9 of the directive is its requirement for 'Nearly Zero-Energy Buildings' from member states is to ensure that "(a) by 31 December 2020, all new buildings are nearly zero-energy buildings; and (b) After 31 December 2018, new buildings occupied and owned by public authorities are nearly zero-energy buildings" (EPBD recast, 2010) [8].

- ASHRAE vision 2020 is to develop energy-related products, tools, guidance, research in the renewable energy system, identification of various activities related to net-zero energy usage for all type of facilities by 2020 which will enable the building community to produce market-viable-net zero energy buildings (NZEB) by the year $2030[9,10]$.

- Barak Obama president of USA, in October 2009 signed an Executive order (EO) 13514 titled "Federal leadership in Environmental, Energy, and Economic Performance". This Executive order entails that all new Federal buildings in 2020 or thereafter be "designed to achieve zero-net-energy by 2030". Additionally, the Executive Order (EO) 13154 requires that at least $15 \%$ of existing buildings over 5000 gross square feet to meet the Guiding Principles for Federal Leadership in High Performance and Sustainable Buildings by 2015 [10].

- International Energy Agency (IEA) investigated solar cooling via solar heating and cooling program. IEA-SHC Task 25 (June 1999 - May 2004) related to the solar assisted air conditioning of the buildings with main objective to improve the conditions for market entry of solar assisted cooling systems to reduce the demand of peak electrical loads and primary energy consumption by air conditioning systems. IEA-SHC task 38 (September 2006 - December 2010) focused on introducing the solarassisted cooling system into the market and development of simulation tools for the evaluation of preengineered cooling systems for small and medium-sized applications for the residential and commercial sector [11].

- IEA-SHC task 53 (March 2014 - June 2017) is assisting to develop a strong and sustainable market of the solar cooling system in the power range of $1 \mathrm{~kW}$ to several tens of $\mathrm{kW}$ for heating and cooling applications in single-family houses, small multi-family buildings, shops, offices, commercial centers, factories, and hotels [12].

- The Net ZEB Evaluation Tool is created (by EURAC Research within subtask A) that enables energy balance, operating cost and load match index calculation for the predefined selected definition of IEASHC Task 40/ECBS Annexure 52 “Towards Net Zero Energy Solar Buildings” IEA-SHC (2017) [13].

- Zero Energy Ready Home program is run by The Department of Energy (DOE) U.S.A to reduce the energy demand of the building sector in America. Zero Energy Ready Homes must have solar panels installed or leave space for future installation [14]. 


\section{TYPES OF NET ZERO ENERGY BUILDINGS (NZEBS)}

In 2008, a research project started with the framework of International Energy Agency "Towards Net Zero Solar Energy" to a harmonized understanding of what is a Net Zero Energy Building [15]. Much research in recent years has been focused on developing a clear definition of the zero-energy building $[8,16]$ as shown in Table 1 because definition affects the designer choices to achieve and claim the success of zero energy goal [17].

Table 1. Comparison of zero energy buildings definitions by balancing component

\begin{tabular}{|c|l|l|l|l|}
\hline S/No & \multicolumn{1}{|c|}{ Type } & $\begin{array}{c}\text { Balancing } \\
\text { cycle }\end{array}$ & $\begin{array}{c}\text { Balancing } \\
\text { component }\end{array}$ & Concerned party/Authority \\
\hline 1 & Net Zero Site Energy & Yearly & Energy & $\begin{array}{l}\text { Building designer for energy } \\
\text { code requirement }\end{array}$ \\
\hline 2 & Net Zero Source Energy & Yearly & Source & Organizations \\
\hline 3 & Net Zero Energy Costs & Yearly & Cost & Building owners \\
\hline 4 & Net Zero Energy emission & Yearly & Emission & $\begin{array}{l}\text { Environmental protection } \\
\text { authorities }\end{array}$ \\
\hline
\end{tabular}

There are many zero energy ready homes in a hot and humid climate of the United State of America (USA) certified by the Department of Energy (DOE) and awarded HERS score. HERS is Home Energy Rating System uses to measure home's energy efficiency. In the case of NZEB, HERS score of zero is required [18]. According to available literature for zero energy ready homes named $\mathrm{e}_{2}$ homes in winter park, Florida annual energy saving is shown $-123 \mathrm{kWh}$ and HER'S index of -7 (negative number indicated the house is producing extra energy and exporting to the grid) [19]. The Amerisps home in Johns Island, HER'S index score of 1 shows that the house is nearly zero energy building [20]. The McKinley project in Garland, HER'S index score is 26 which shows that the house is 74\% more efficient than reference building modelled as per IECC-2009 [21].

\section{PROBLEM STATEMENT}

A comparison study of NZEBs showed that all the buildings consumed more energy and produced less energy than predicted in the design/ simulation stage [22]. Some of the key factors adversely affecting the actual energy consumption of the residential building as compared to the simulated results are software limitations, model simplifications, changes between predicted and the final building construction, occupant's behavior, commissioning, controls, management, operation, and maintenance [23].

This paper presents the energy analysis of Net Zero Energy Building with Energy Recovery Ventilator (ERV) and without ERV in Muscat, Oman. Section 2 springs an introduction to the Eco house (NZEB) competition rules, Section 3 explained the research methodology adopted to perform energy analysis of the house by HAP software, Section 4 presents the energy analysis results and provided a comparison to the actual energy consumption of NZEB recorded by data acquisition system (DAS) and predicted by the HAP software.

\section{BACKGROUND}

The objective of Eco house (NZEB) constructed at Higher College of Technology, Muscat was to participate in a design competition sponsored and organized by The Research Council (TRC) of Oman. The competition rules were alike solar decathlon competition as shown in Table 2. In this competition, eight contests were considered by the organizer. Five contests were juried based and three contests were on measurement basis. The jury evaluated proposal, scale model, drawings, construction specifications, audiovisual presentations for architecture, engineering and sustainability contests and final constructed project. The communication jury evaluated dedicated website for the project, video walkthrough, onsite public exhibition and public exhibit material.

Data Acquisition System (DAS) was installed to measure temperature and relative humidity of all living spaces of the house. DAS also measured energy consumption of refrigerator, freezer, clothes washer, induction cooker, and dishwasher, lighting and home electronics during the contest period of one month. Energy balancing contest task was to produce as much energy $(\mathrm{kWh})$ as consumed by the house during the contest period with the PV system. 
Table 2. Contest criteria for eco-house competition in Oman [24]

\begin{tabular}{|c|c|c|c|}
\hline Contest Name & Points & $\begin{array}{l}\text { Type of } \\
\text { Contest }\end{array}$ & Brief Description \\
\hline $\begin{array}{l}\text { Conceptual design and } \\
\text { Design development }\end{array}$ & 100 & \multirow[t]{5}{*}{ Juried } & $\begin{array}{l}\text { CD/DD jury evaluate the proposal, scale model, and display } \\
\text { boards }\end{array}$ \\
\hline Architecture & 100 & & $\begin{array}{l}\text { Architect Jury evaluates drawings, construction specifications, } \\
\text { audiovisual architecture presentation, and final constructed } \\
\text { project }\end{array}$ \\
\hline Engineering & 100 & & $\begin{array}{l}\text { Engineering Jury evaluates drawings, energy analysis } \\
\text { construction } \quad \text { specifications, audiovisual engineering } \\
\text { presentation, and final constructed project }\end{array}$ \\
\hline Sustainability & 100 & & $\begin{array}{l}\text { Sustainability Jury evaluates drawings, construction } \\
\text { specifications, audiovisual sustainability presentation, and final } \\
\text { constructed project }\end{array}$ \\
\hline Communications & 100 & & $\begin{array}{l}\text { Communications Jury evaluates a website, video walkthrough, } \\
\text { onsite public exhibit, and public exhibit materials }\end{array}$ \\
\hline \multicolumn{4}{|c|}{ Comfort Zone. Temperature and relative humidity measurement } \\
\hline Temperature & 75 & Measured & Keep all living spaces at $25^{\circ} \mathrm{C}-27^{\circ} \mathrm{C}$ range \\
\hline Humidity & 25 & Measured & Keep all living spaces in $50 \%$ to $70 \%$ relative humidity \\
\hline \multicolumn{4}{|c|}{ Appliances lighting Electronics } \\
\hline Refrigerator & 10 & \multirow[t]{9}{*}{ Measured } & Keep the refrigerator at $1.1^{\circ} \mathrm{C}$ to $4.4^{\circ} \mathrm{C}$ range \\
\hline Freezer & 10 & & Keep freezer at $-29^{\circ} \mathrm{C}$ to $-15^{\circ} \mathrm{C}$ range \\
\hline Hot Water & 10 & & $\begin{array}{l}\text { Deliver } 150 \mathrm{~L} \text { of water at an average } 43^{\circ} \mathrm{C} \text { temperature within } \\
30 \text { minutes }\end{array}$ \\
\hline Clothes Washer & 10 & & Successfully wash load (six bath towels) of laundry \\
\hline Cooking & 30 & & Successfully perform a cooking task (vaporize 3.00 in. of water) \\
\hline Dishwasher & 10 & & Successfully wash a load (six place setting) of dishes \\
\hline Lighting & 10 & & $\begin{array}{l}\text { Keep all interior and exterior lights on at full levels during } \\
\text { specific night-time }\end{array}$ \\
\hline Home Electronics & 10 & & Operate TV and computer during specific hours \\
\hline Energy Balance & 100 & & $\begin{array}{l}\text { Produce at least as much electrical energy }(\mathrm{kWh}) \text { as is consumed } \\
\text { during the evaluation period }\end{array}$ \\
\hline Totals & 800 & & 500 juried points and 300 measured points \\
\hline
\end{tabular}

\section{RESEARCH METHODOLOGY}

Building energy simulation programs are used by energy experts to predict the energy performance of buildings. There is many building energy simulation software's recommended by United State Green Building Council (USGBC) for LEED certification of the buildings, for example; Trance TRACE, Carrier HAP, e QUEST, Energy 10, TRNSYS, Energy Plus, Energy Pro and Visual DOE [25]. Energy analysis in this research work was performed by Carrier HAP software. Energy analysis was performed to estimate the annual energy use and energy cost for the building.

\section{DATA GATHERING AND ENTERING IN HAP}

To perform an energy analysis in HAP software number of steps were involved. Step one was involved modification in design conditions of the dry bulb and wet bulb temperature in given weather data for Seeb International Airport (Muscat) in HAP directory. Design conditions modified as per the recommendation of 
cooling load expert from the industry because of the poor performance of HVAC systems due to design conditions recommended by the software. To model the heat transfer of each room in HAP software, detailed information of walls, roofs, windows, external shading, doors, lightings, and occupants was collected. Step three was involved to gather information about the air system. In the next step, data was entered in the HAP software and design report was generated. In next step system design reports were used to select HVAC equipment.

To estimate annual energy use and energy cost for a building electric rate data was collected and entered into HAP software. The data for fuel was not collected because the house understudy was allowed to use electricity only. In next step data for the selected HVAC system and electric rate, and pricing was structured in building container available in the software. After entering all the required data energy analysis calculation was performed and simulation reports were generated for annual components cost, monthly energy used by energy type.

\section{ENERGY BALANCING}

The PVWatts calculator was used by the team to predict the power generation by the $77 \mathrm{PV}$ panels installed on the top of the roof in the form of a canopy. The simulation results were very appreciating because of possibility to balance the energy demand of the house every month which is very difficult to achieve as compared to year around energy balancing.

\section{NET ZERO ENERGY BUILDING: CASE STUDY}

The two-story Net Zero Energy Building (well known as Eco house) at Higher College of Technology (HCT), Muscat, Oman has covered floor area of $230.7 \mathrm{~m}^{2}$. The house consists of one Majlis, Dining Room, Living room, and Kitchen on the ground floor. The first floor consists of a master bedroom, one bedroom for kids, and one bedroom for guests. The house is designed to maintain temperature in the range of $25^{\circ} \mathrm{C}-27^{\circ} \mathrm{C}$ and relative humidity in the range of $50 \%-70 \%$ throughout the year powered by grid-tied solar energy system of $22.8 \mathrm{~kW}$ (DC rating) facing towards south at angle of $5^{\circ}$ (fixed array) on the top of the house in the form of canopy as shown in the Figure 1.

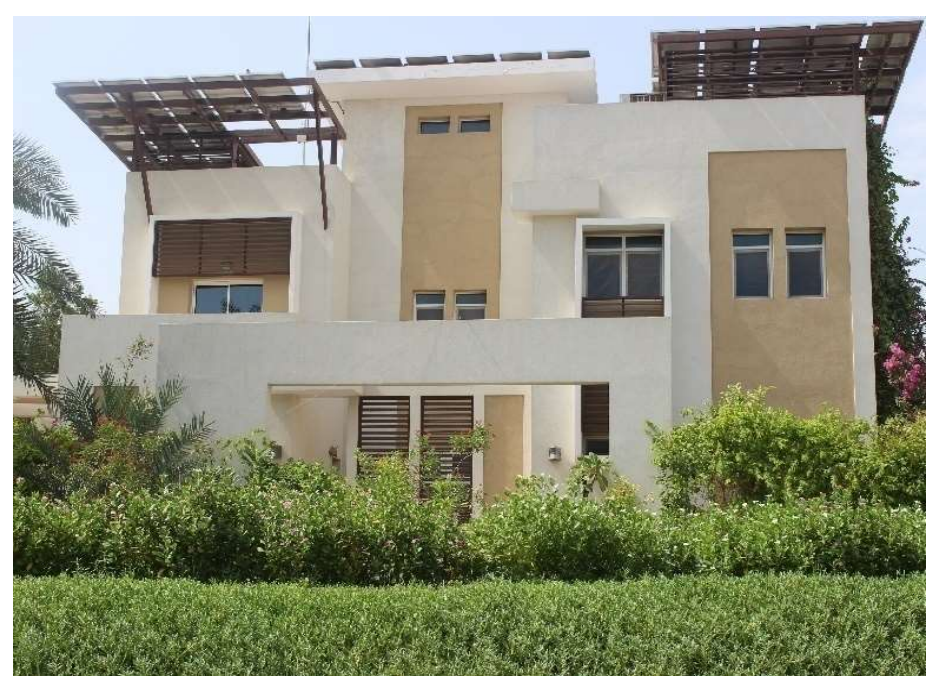

Figure 1. Net-zero energy building at higher college of technology Muscat

The house was constructed by Insulated Concrete Forms (ICF) wall system with U value of $0.233 \mathrm{~W} / \mathrm{m}^{2}$. $\mathrm{K}$, the roof of hollow-core slabs of $\mathrm{U}$ value $0.339 \mathrm{~W} / \mathrm{m}^{2} . \mathrm{K}$ additionally covered by solar panels, double glazed windows of a shading coefficient of 0.28 with overall $\mathrm{U}$ value of $1.88 \mathrm{~W} / \mathrm{m}^{2} . \mathrm{K}$, and certified wooden doors of $\mathrm{U}$ value of $3.62 \mathrm{~W} / \mathrm{m}^{2}$. K help to achieve the set target of energy balance during the competition period. The house was also equipped with energy recovery ventilators one for each floor, and variable refrigerant volume heat pumps one for each floor to achieve the comfort conditions in year-around operation. Solar hot water system with electric backup, freezer, refrigerator, clothes washer, induction cooker, dishwashers, home electronics, internal and external lightings was installed in the house to perform different tasks recommended by the 
competition organizer. The final constructed NZEB (Eco house) at Higher College of Technology, Muscat had twenty sustainable features as shown in Table 2. These innovative features enabled the NZEB (Eco House) team to achieve the target of Net Zero Energy Building for the competition period.

Table 3. Sustainable features of the house

\begin{tabular}{|l|l|l|l|}
\hline S/No & Sustainable Feature Description & S/No & Sustainable Feature Description \\
\hline 1 & Appropriate sizing/ Number of floors & 11 & Food and low water plants \\
\hline 2 & North-South oriented building & 12 & Environmental friendly refrigerant \\
\hline 3 & Insulation of wall (NADURA ICF), roof and floor & 13 & Energy Recovery Ventilator \\
\hline 4 & Double glazed windows & 14 & Greywater treatment system \\
\hline 5 & External Shading & 15 & Rainwater collection \\
\hline 6 & Cross flow ventilation & 16 & The solar hot water system \\
\hline 7 & Certified wood (FSC certified) & 17 & Energy generation onsite by solar panels \\
\hline 8 & Vertical green wall ( West wall) & 18 & The solar mobile charging station \\
\hline 9 & LED Lighting & 19 & Real-time energy and water usage display \\
\hline 10 & 5-Star energy-efficient appliances & 20 & Paints with low toxicity \\
\hline
\end{tabular}

The house was equipped with Data Acquisition System (DAS) to monitor performance and administrative measured contests related to comfort zone contest, refrigerator sub contest, freezer sub contest, hot water, clothes washer, cooking, dishwasher, lighting and home electronics tasks, and energy balance contest as shown in Table 2 .

The Data Acquisition System (DAS) as shown in Figure 2 is composed of Data logger (low voltage) enclosure, Watt-Node (high voltage enclosure), sensors for refrigerator, freezer, comfort zone testing, weather station, current transformers and connectors necessary for the evaluation of the house. Watt-Node and Current transformers are used to measure the energy consumption and production by PV panels installed on the house during the contest period. Net energy consumption results displayed by bi-directional meter capable to measure energy coming from the grid and PV panels respectively.

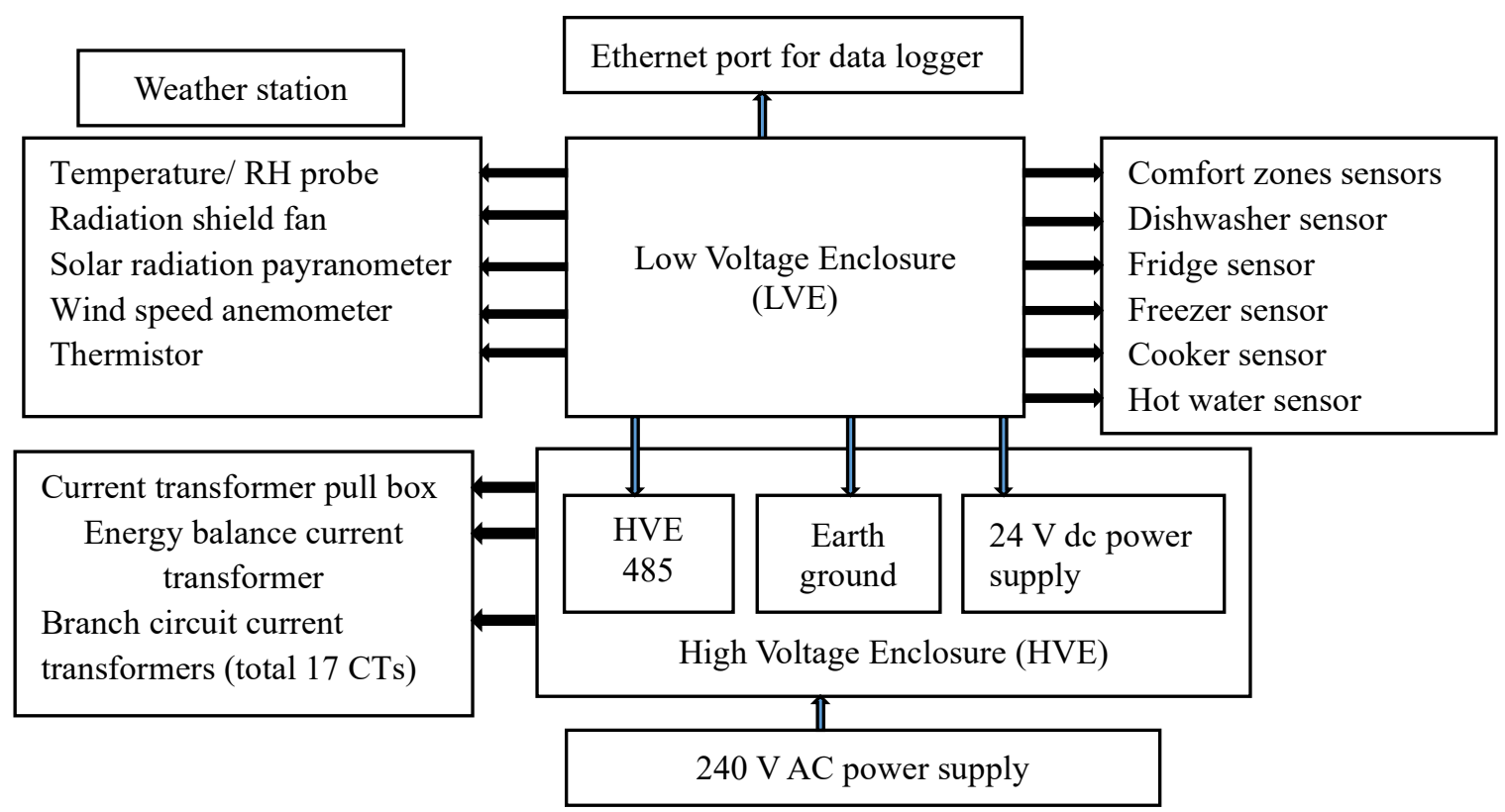

Figure 2. Data acquisition system line diagram for net-zero energy building 


\section{ENERGY ANALYSIS RESULTS}

Average HVAC load on the central cooling coil is presented in Figure 3. The typical summer profile was taken from the average data from May to October 2014 along with July and August 2014. The large spike between 8:am to 10:am was due to the entry of six students for performing multiple tasks including cooking, water heating, electric lights switch on and operation of the home appliance.

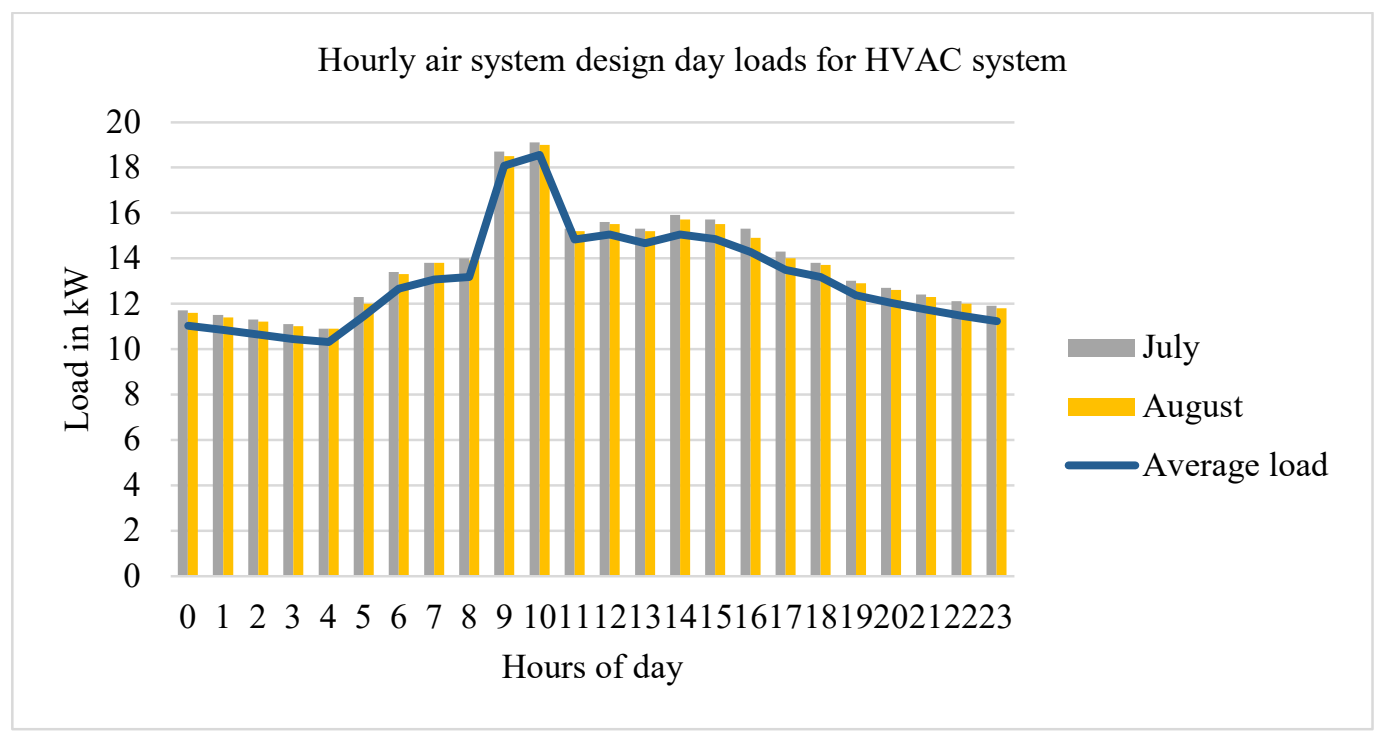

Figure 3. Hourly air system design day loads for HVAC system

The simulation results of zone design load for the building envelope, lighting, people, and electric equipment are shown in Figure 4. The results indicated $30 \%$ of total cooling load added by electric equipment, whereas $7 \%$ to $14 \%$ added by windows, wall, roof, and lighting system.

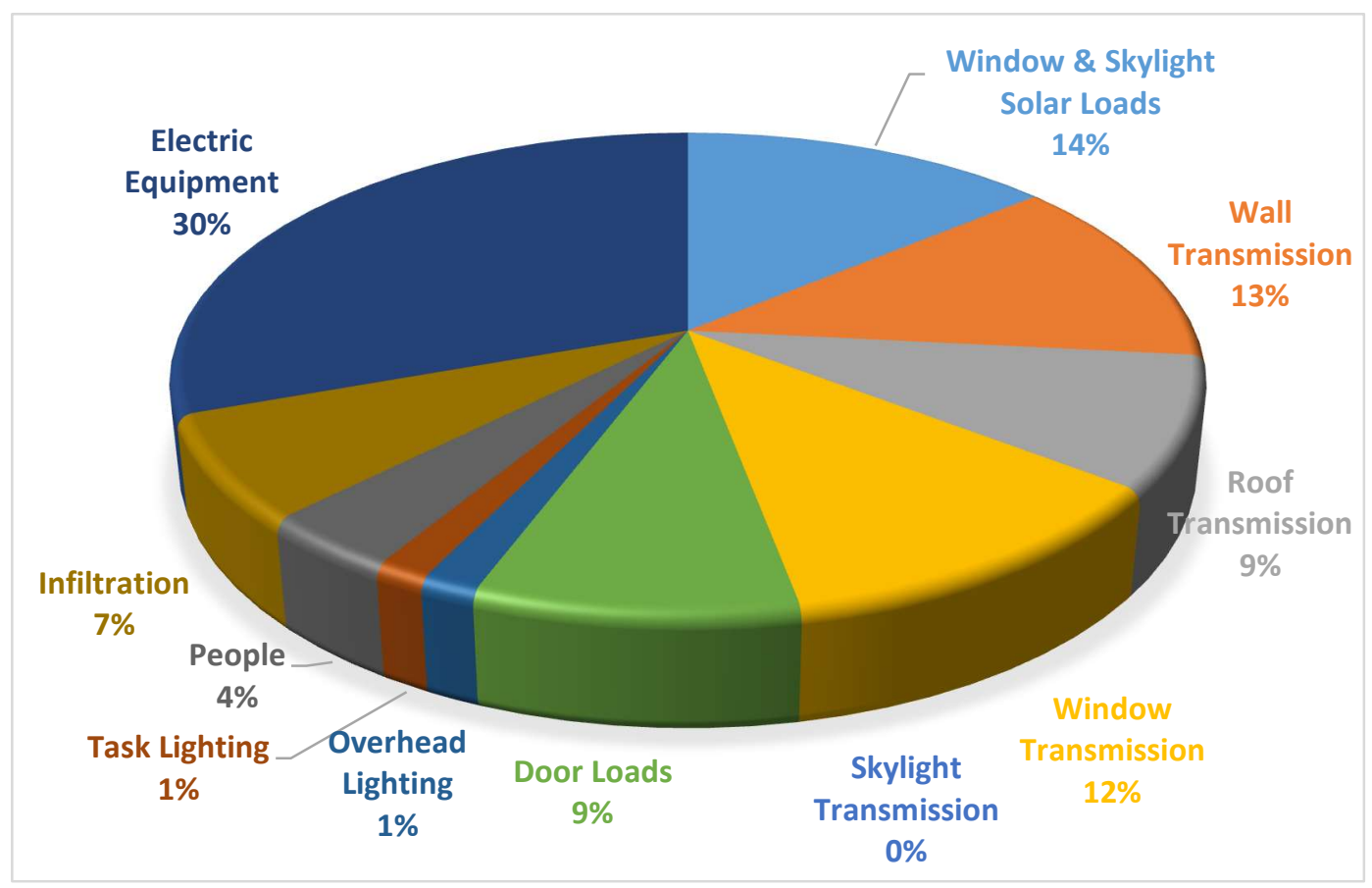

Figure 4. Zone design load summary 
The results in Figure 5 indicated the energy demand of same size regular house had U-values of 1.319 $\mathrm{W} / \mathrm{m}^{2}$. K, $2.025 \mathrm{~W} / \mathrm{m}^{2}$. K, 5.08 to $6.88 \mathrm{~W} / \mathrm{m}^{2} . \mathrm{K}, 0.568 \mathrm{~W} / \mathrm{m}^{2}$. K, 3.5 to $4.5 \mathrm{~W} / \mathrm{m}^{2}$. K for the wall, roof, windows, slab on grade and doors respectively. The predicted results showed that energy demand of NZEB (Eco house) is 34.37 \%less than regular house mainly due to $69.5 \%$ less HVAC and $23.16 \%$ Non-HVAC load respectively. As can be seen, the energy demand of NZEB was lower than a regular house, which is consistent with the result obtained by The United Nation Environmental Program (UNEP) by using proven strategies and technologies in energy-efficient buildings is estimated to reach between $30 \%$ to $80 \%$ [26].

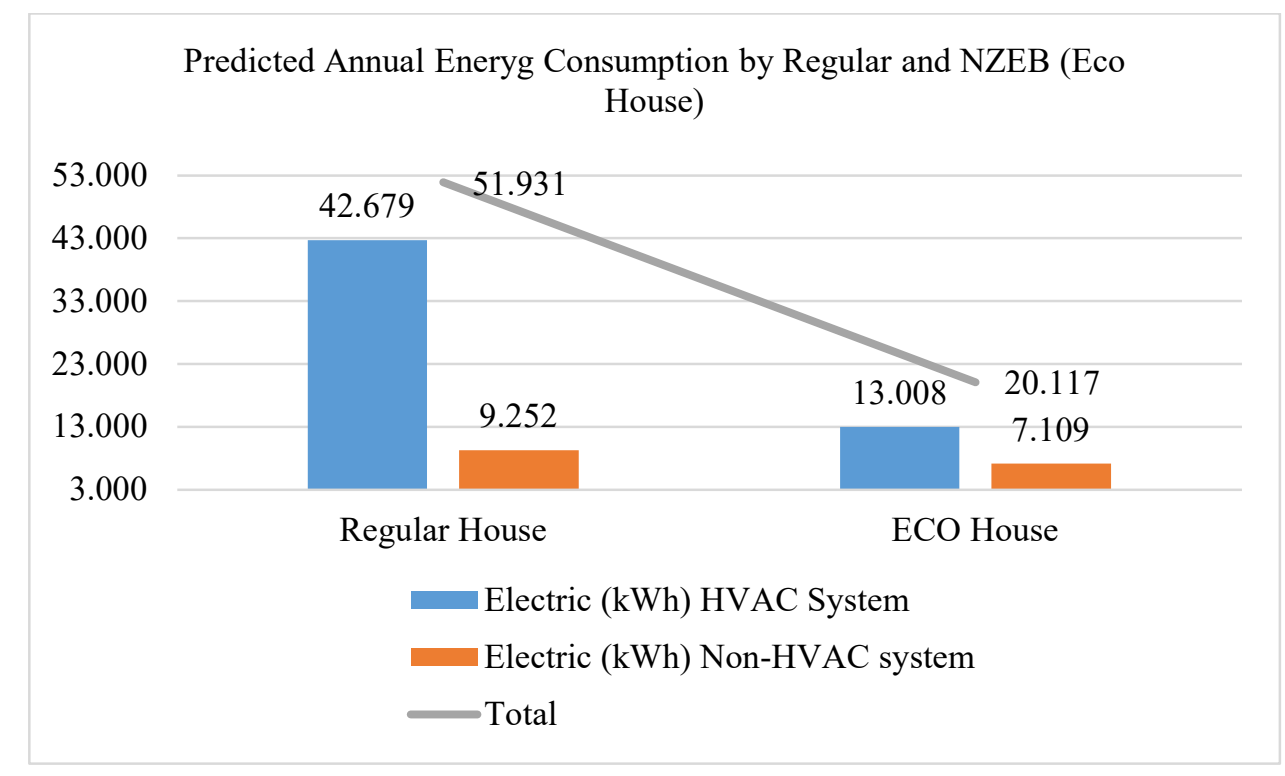

Figure 5. Annual energy consumption by regular and NZEB (Eco House)

Building Energy Index is a measure of total energy usage of the house in one year divided by the total floor area of the house. In this case study, only predicted BEI by the simulation tool for the regular house of the same size and NZEB (Eco house) presented because actual energy consumption data was not available for houses under the same operating conditions as mentioned in Table 1. As predicted by the simulation tool, Building Energy Intensity (BEI) of Net Zero Energy Building (NZEB) at HCT was $87.20 \mathrm{kWh} / \mathrm{m}^{2} / \mathrm{yr}$. which was $61.24 \%$ less than the same size regular house in Muscat and $27.08 \%$ less than the required value by the Passive House Institute (PHI) which is $120 \mathrm{kWh} / \mathrm{m}^{2} /$ year [26].

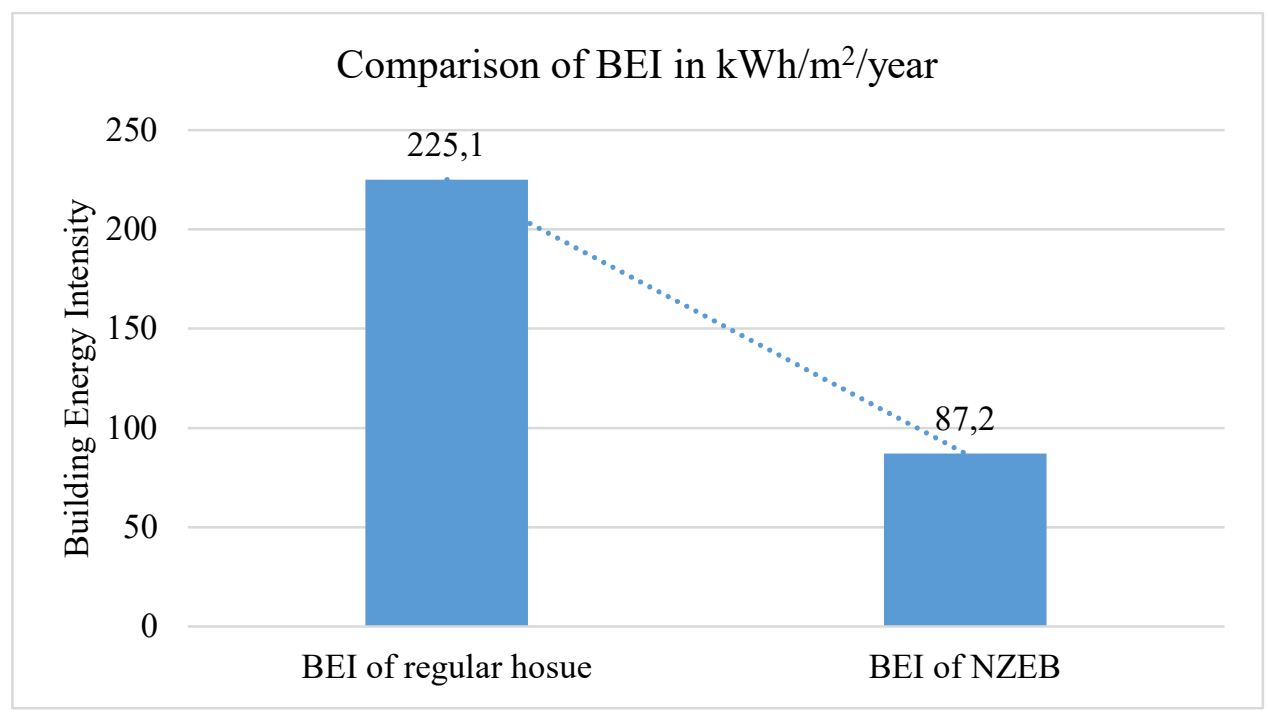

Figure 6. Building energy intensities of regular and net-zero energy building at HCT 
Actual and predicted energy consumption results of HVAC and Non-HVAC systems for competition period shown in Figure 7. Comparison of results highlighted that energy consumption by HVAC system predicted by HAP software is only 5\% extra as consumed by HVAC system in actual during the competition period whereas energy consumption by Non-HVAC system predicted by HAP software is $27.56 \%$ higher than consumed by house because Energy Recovery Ventilator (ERV) and grey water pump were not operated during the competition period. The HVAC system of the house consumed $44 \%$ and Non-HVAC system consumed $56 \%$ of the total energy consumed by the house during the contest period.

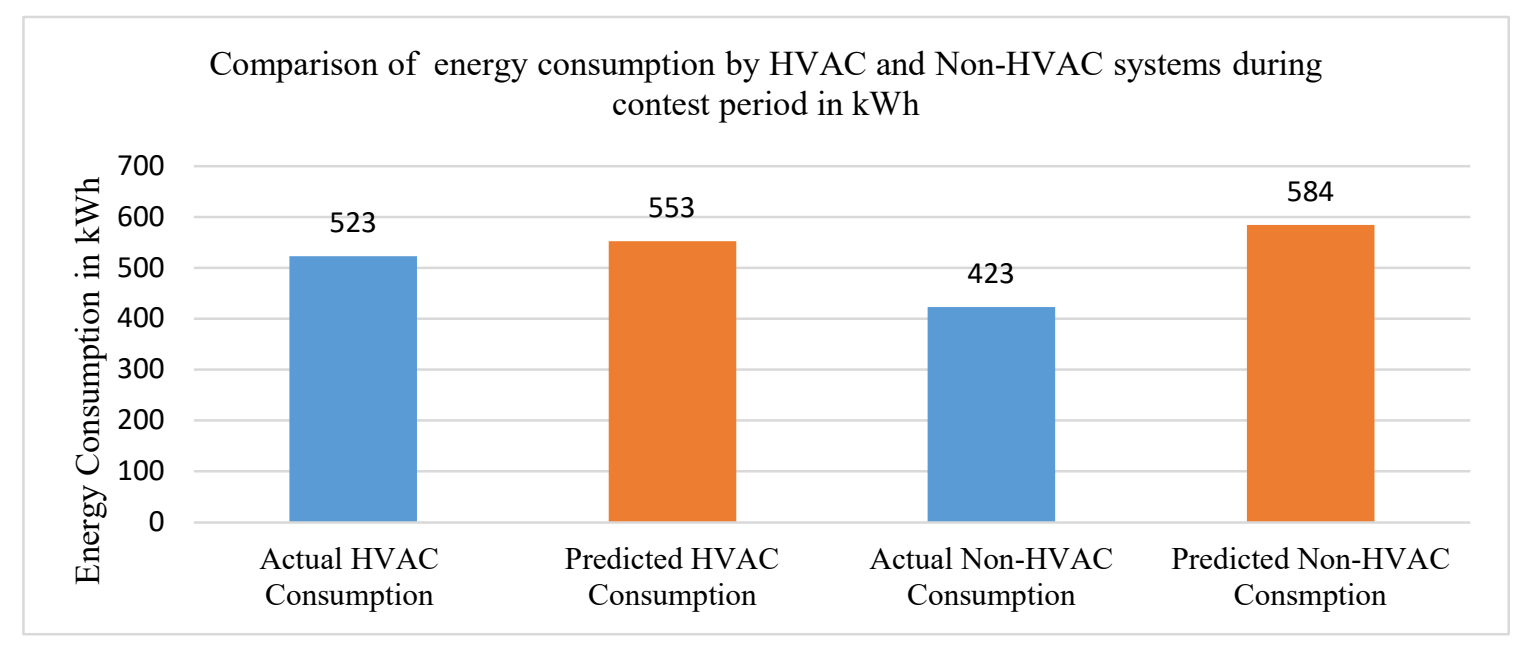

Figure 7. Comparison of energy consumption by HVAC and Non-HVAC system during contest period in kWh

Actual energy consumption by electrical equipment during the contest period is shown in Figure 8 . Actual energy consumption results show that HVAC system consumed $55.26 \%$ of total energy, lighting system $14.95 \%$, cooktop $6.84 \%$, and water heater $6.31 \%$, fridge-freezer $3.8 \%$, dishwasher $2.68 \%$, and clothes washer $0.95 \%$, home electronics $1.06 \%$, DAS $1.08 \%$ and unmeasured electrical load $1.57 \%$ respectively. The results obtained for HVAC system consumption are similar to the results reported by other researchers for the HVAC system in the range 50\% and above [27].

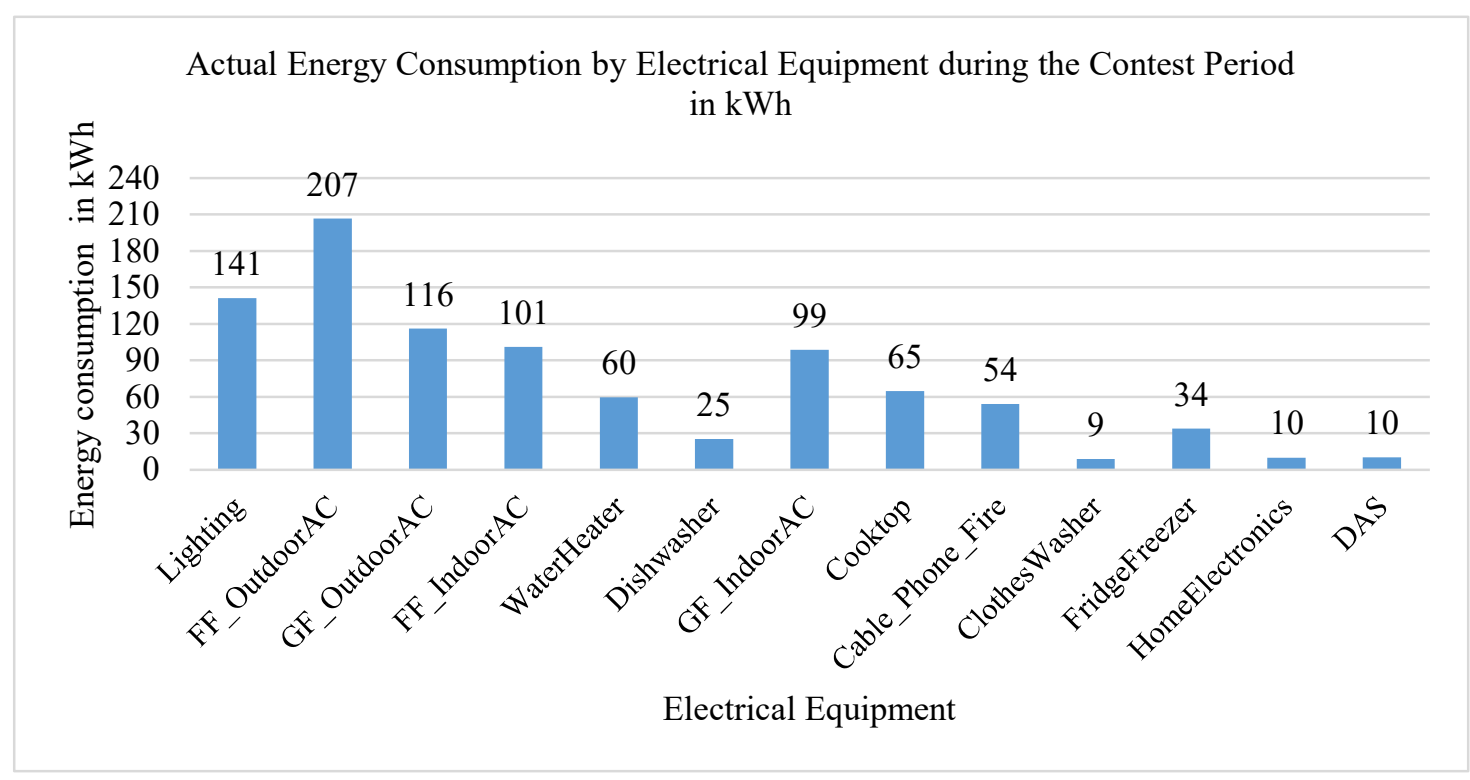

Figure 8. Actual energy consumption by all electrical equipment during the contest 
The PVWatts calculator results predicted the possible output of solar system installed in the Net Zero Energy Building (NZEB) was $34239 \mathrm{kWh}$ in one year. PVWatts calculator predicted production of $2183.5 \mathrm{kWh}$ during the competition month from November 18, 2014, to December 16, 2014. However, during the competition period, the solar system installed on the roof produced $2167.77 \mathrm{kWh}$ which is only $0.73 \%$ less than predicted values as shown in Figure 9.

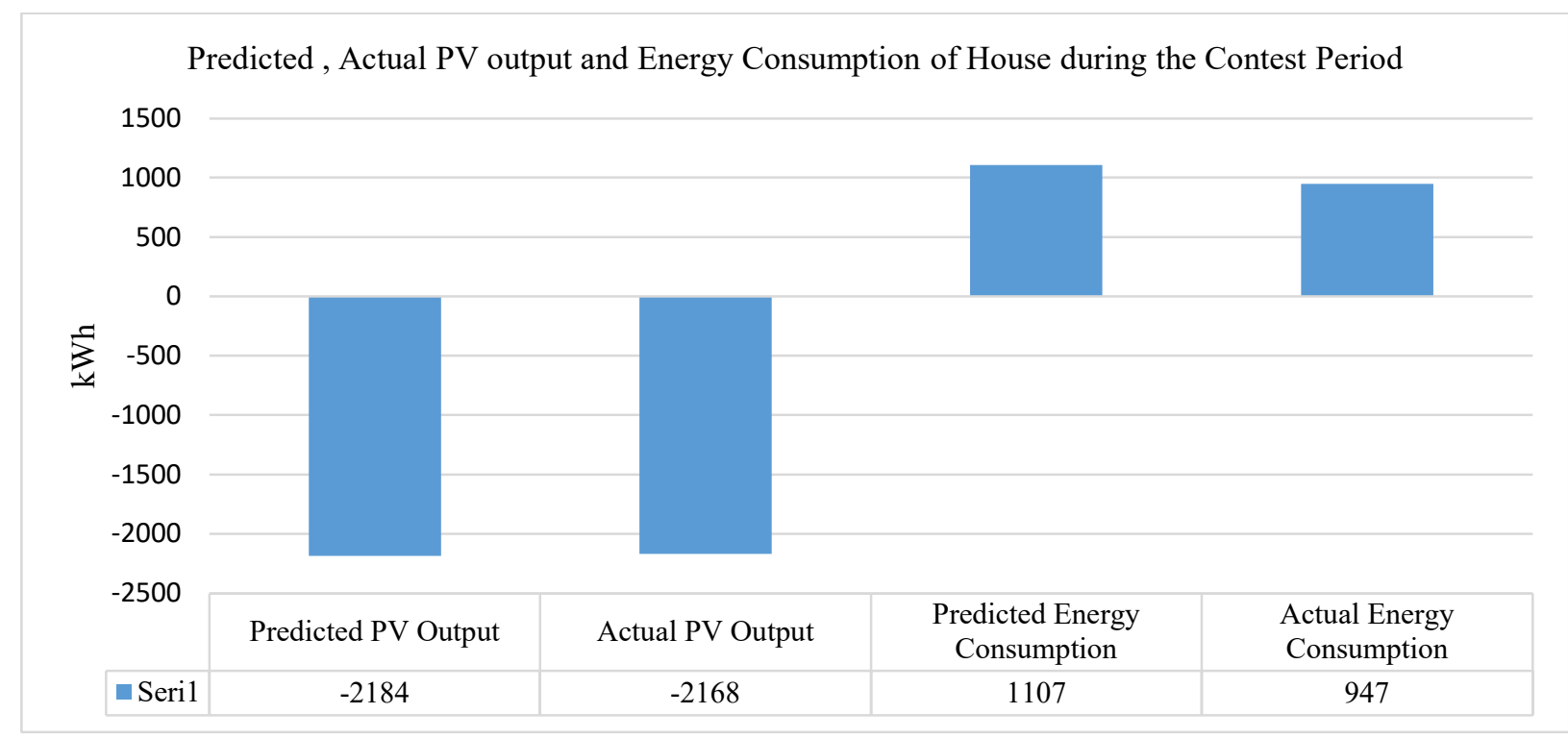

Figure 9. Predicted and actual PV output and energy consumption of a house

Comparing energy consumption and energy production results presented in Figure 10 that Net Zero Energy Building is capable to achieve net-zero energy status every month. The results of Figure 10 show that Net Zero Energy House can be produced $32.7 \%$ extra energy in peak energy-demanding month of June to $64.5 \%$ extra in February with least energy demand. The results show that even with a safety margin of $10 \%$ house can achieve net-zero energy status on an annual basis with a $40 \%$ smaller PV system installed on the house.

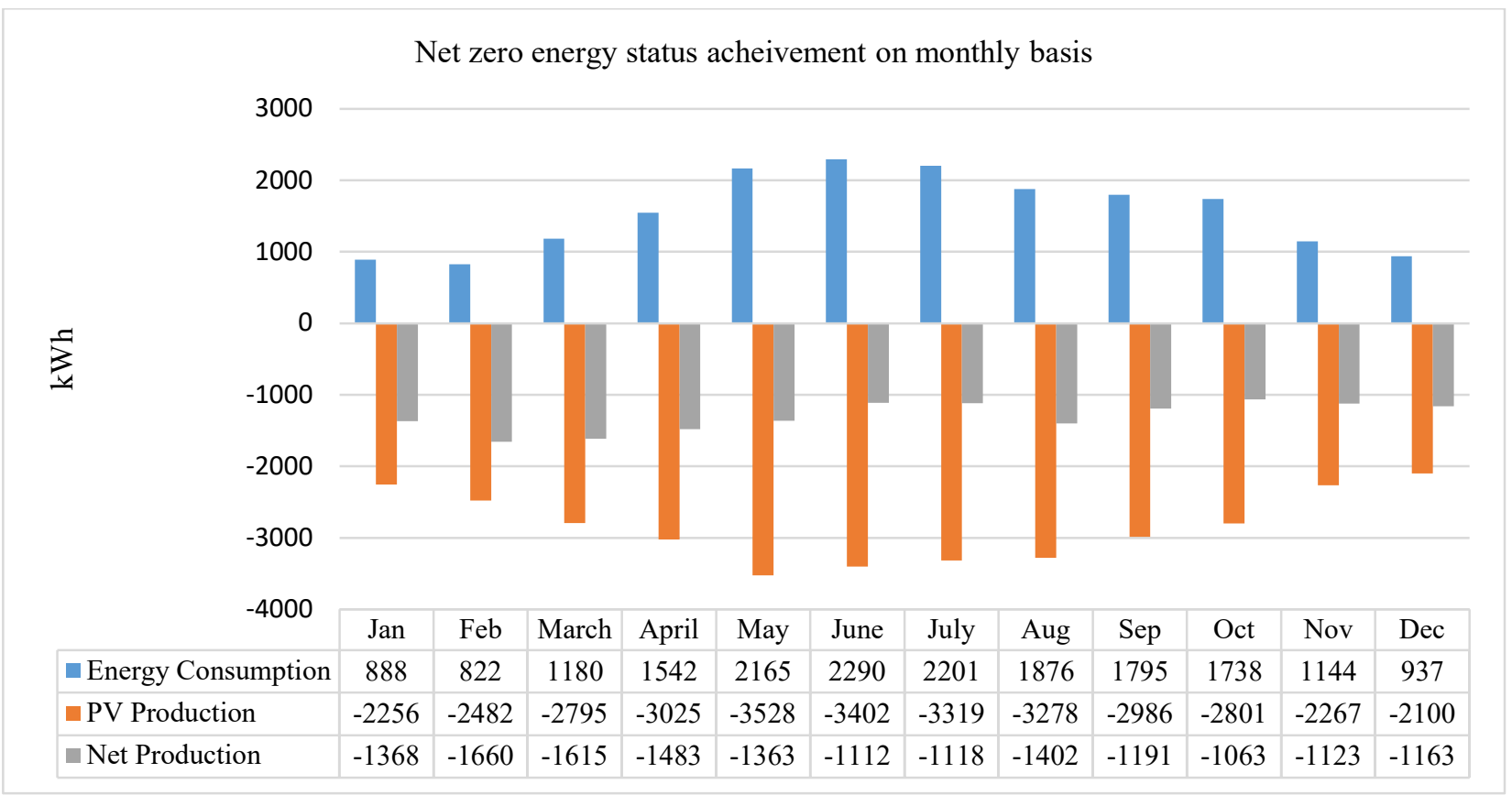

Figure 10. Monthly net-zero energy building status achievement 
The results from data acquisition system installed in Net Zero Energy Building show in Figure 11 that Net Zero Energy Building (Eco House) achieved plus Net Zero Energy Building status during the contest period and exported $1221 \mathrm{kWh}$ energy to the grid.

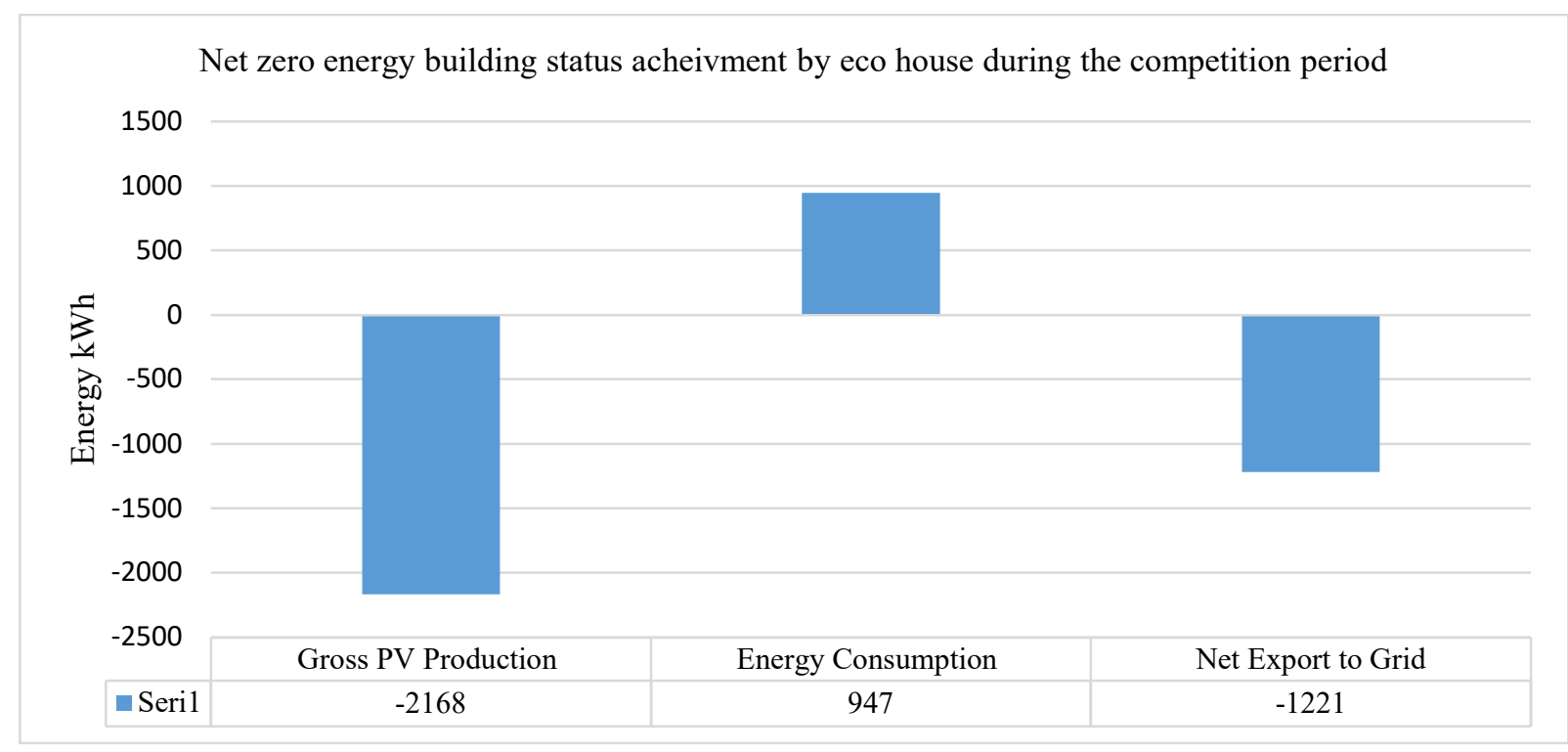

Figure 11. Net-zero energy building status achievement in the contest month

Energy cost was calculated in US dollar (\$) because Omani Rial option is not available. The unit price of one $\mathrm{kWh} 0.010 \mathrm{OMR}=0.025 \$$ is used for this cost analysis whereas $1 \mathrm{OMR}=2.59$ US $\$$. The results in Figure 12 show that operational energy cost of NZEB is $45 \%$ to $67 \%$ less than the same size regular house in different months.

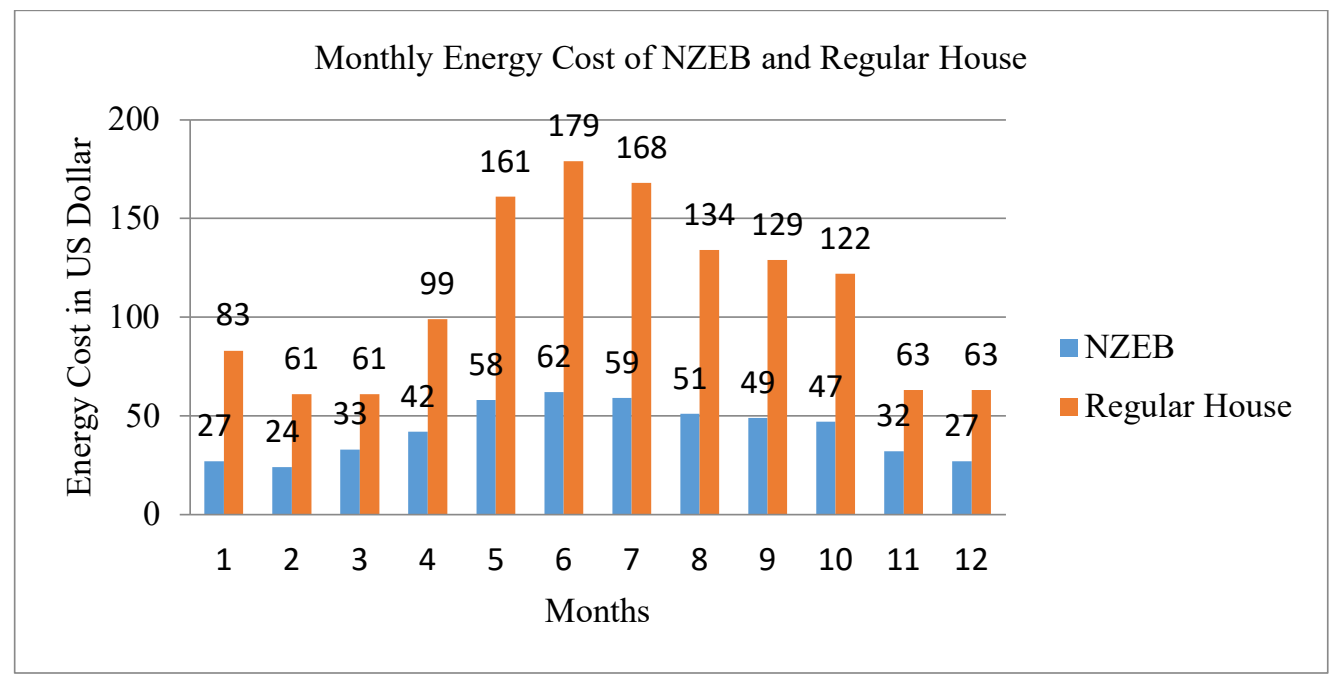

Figure 12. Monthly energy cost comparison

\section{CONCLUSION}

Detailed energy analysis of NZEB at HCT, Muscat was performed with HAP software and calculation for energy balancing was performed with PVWatts calculator. This study compares actual and predicted energy usage in Net Zero Energy Building at Higher College of Technology, Muscat, Oman. Comparison of monthly energy consumption has shown that amount of energy consumed by the HVAC system is $5 \%$ less than predicted by HAP software whereas the energy consumed by the non-HVAC system is $30 \%$ less than predicted by HAP software because Energy Recovery Ventilator (ERV) and grey water pump were not operated during the competition period. 
The simulation result for BEI of NZEB and same size regular house shows that BEI of NZEB is $61.24 \%$ less than same size regular house due to sustainable features added in the building. The study also indicates that grid-tied solar system installed on the top of the house produced the approximately same amount of energy as predicted by the online simulation tool PVWatts calculator for the competition period.

Most notably, this is one of the first attempts to construct net-zero energy building in Muscat successfully and results are very encouraging to construct many net-zero energy buildings in GCC region to reduce energy demand and $\mathrm{CO} 2$ contribution by building sector.

It is vital to understand the limits of HAP software. This software is not capable to integrate some of the passive features of the house like green wall effects, shading by solar panels on the roof, and daylighting control effect in the energy analysis of the building due to this variation in the building thermal load is possible. The next step for this research work is to perform energy simulation in two additional software, eQUEST and Autodesk Revit and comparison of these results with HAP results and actual energy consumption of the building for a whole year.

\section{NOMENCLATURE}

$\begin{array}{ll}\text { BEI } & \text { Building energy intensity } \\ \text { CO2 } & \text { Carbon dioxide } \\ \text { DC } & \text { Direct current } \\ \text { DAS } & \text { Data acquisition system } \\ \text { ERV } & \text { Energy recovery ventilator } \\ \text { HAP } & \text { Hourly analysis program } \\ \text { HERS } & \text { Home energy rating system } \\ \text { HVAC } & \text { Heating ventilation and air conditioning } \\ \text { ICF } & \text { Insulated concrete forms } \\ \text { kWh } & \text { Kilo watt hour } \\ \text { LEED } & \text { Leadership in energy and environmental design } \\ \text { NZEB } & \text { Net zero energy building } \\ \text { PV } & \text { Photo voltaic } \\ \text { PHI } & \text { Passive house institute } \\ \text { USGBC } & \text { United States green building council } \\ \text { UNEP } & \text { United Nation environmental program }\end{array}$

\section{REFERENCES}

[1] IEA, UNDP. Modernising Building Energy Codes to secure our Global Energy Future: Policy Pathway. 2013;70. Available from: www.iea.org [Accessed 10th March 2017]

[2] Kamal MA. An Overview of Passive Cooling Techniques in Buildings : Design Concepts and Architect ural Interventions. Acta Tech Napocensis: Civil Eng Archit 2012;55(1).

[3] Zuha Maksood F, Achuthan G. Sustainability in Oman: Energy Consumption Forecasting using R. India n J Sci Technol. 2017;10(10):1-14. https://doi.org/10.17485/ijst/2017/v10i10/97008.

[4] Torcellini P, Pless S, Deru M, Crawley D. Zero Energy Buildings: A Critical Look at the Definition. AC EEE Summer Study Pacific Grove. 2006;15. Available from: http://www.nrel.gov/docs/fy06osti/39833. pdf

[5] Banerjee R. Importance of Net Zero Energy Building. Int J Innov Res Adv Eng. 2015;2(5):141-5.

[6] Garde F, David M, Lenoir A, Ottenwelter E. Towards net zero energy buildings in hot climates: Part 1, new tools and methods. In: ASHRAE Transactions. 2011. p. 450-7.

[7] Workshop of APEC Nearly (Net) Zero Energy Building Roadmap.Available from http://www.apec.org//mediaAPEC/Publications/2018/12/APEC-Nearly-Net-Zeo-Energy Building Roadmap/2018_EWG_AP EC-NZEB-Road-study.pdf

[8] Marszal J, Heiselberg P. Zero Energy Building definition - a literature review: A technical report of subt ask A. Task40/Annex52. 2012; 1-16.

[9] ASHRAE.ASHRAE Vision 2020: Producing Net Zero Energy Buildings.Available from: https://www.as hrae.org/File\%20Library/About/Strategic\%20Plan/ASHRAE---Vision-2020-Report.pdf

[10] Torcellini P, Pless S, Lobato C, Hootman T. Main Street Net-Zero Energy Buildings : The Zero Energy 
Method in Concept and Practice Preprint. 2010;(July).

[11] Baldwin C, Cruickshank CA. A review of solar cooling technologies for residential applications in Cana da. Energy Procedia. 2012;30:495-504. Available from: http://dx.doi.org/10.1016/j.egypro.2012.11.059

[12] Mugnier D, Fedrizzi R, Thygesen R, Selke T. New Generation Solar Cooling and Heating Systems with İEA SHC Task 53: Overview and First Results. In: Energy Procedia. Elsevier B.V.; 2015. p. 470-3. http s:/doi.org/10.1016/j.egypro.2015.02.149

[13] Kim JH, Kim HR, Kim JT. Analysis of photovoltaic applications in zero energy building cases of IEA S HC/EBC Task 40/Annex 52. Sustain. 2015;7(7):8782-800. https://doi.org/10.3390/su7078782

[14] Vonthoma E, Mosiman G. U. S. Department of Energy Zero Energy Ready Home Implementation. 2017 . https://doi.org/10.2172/1373344.

[15] Garde F, Lenoir A, Scognamiglio A, Aelenei D, Waldren D, Rostvik HN, et al. Design of net zero energ y buildings: Feedback from international projects. Energy Procedia. 2014;61(November 2008):995-8. h ttps:/doi.org/10.1016/j.egypro.2014.11.1011.

[16] Marszal AJ, Bourrelle J, Musall E, Heiselberg P, Gustavsen A, Voss K. Net Zero Energy Buildings - Cal culation Methodologies Versus National Building Codes. In 2016. p. 1-8.

[17] Sartori I, Napolitano A, Voss K. Net zero energy buildings: A consistent definition framework. Energy B uild. 2012;48:220-32. Available from: http://dx.doi.org/10.1016/j.enbuild.2012.01.032

[18] RESNET. What is HERS Index?. 2014. p. 1-4. Available from: http://www.resnet.us/hers-index

[19] Rob S. e2 Homes.Winter Park Florida. DOE Home Innov Award 2013.Available from: http://www.buil dingamerica.gov/challenge PNNL-SA93080 January 2013

[20] Bolus R. Amerisips Homes: Custom Designed Residence Johns Island, SC. DOE Home Innov Award. 2 014;3. Available from: https://www.energy.gov/sites/prod/files/2015/06/f22/DOE_ZEH_Amerisips_0920-14.pdf

[21] Carl Franklin Homes: L.C./Green Extreme Homes, CDC, McKinley Project, Garland TX.DOE Home In nov Award. 2015;3-6. Available from: https://www.energy.gov/eere/buildings/downloads/doe-zero-ener gy-ready-home-case-study-carl-franklin-homes-lcgreen-extreme

[22] Torcellini P, Pless S, Deru M, Griffith B, Long N, Judkoff R. Lessons Learned from Case Studies of Six High- Performance Buildings Lessons Learned from Case Studies of Six High-Performance Buildings. Report-National Renew Energy Lab US. 2006;(June).

[23] Attia S, Herde A De. Early Design Simulation Tools for Net Zero Energy Buildings : a Comparison of T en Tools Design Process \& Tools of Nzeb. Proc Build Simul. 2011;94-101.

[24] TRC: Oman Eco House Design Competitions Rules. 2014. Available from:https://ecohouse.trc.gov.om/e cohouse/about/rules/ [Accessed 17th Feburary 2017]

[25] Bob F. Approved LEED simulation software packages. Available from : http://energy-models.com/blog/ list-approved-leed-simulation-software-packages [Accessed 27th May 2018]

[26] Alalouch C, Saleh MS, Al-saadi S. Energy-Efficient House in the GCC Region.Procedia- Social and Be havioral Sciences 216 (2016) 736 - 743. https://doi.org/10.1016/j.sbspro.2015.12.071

[27] Pérez-Lombard L, Ortiz J, Pout C. A review on buildings energy consumption information. Energy Buil d. 2008;40(3):394-8. https://doi.org/10.1016/j.enbuild.2007.03.007 